validation of a brief screen for personality disorder. Br J Psychiatry 2003 183: 228-32.

20 Gorwood P, Rouillon F, Even C, Falissard B, Corruble E, Moran P. Treatment response in major depression: effects of personality dysfunction and prior depression. Br J Psychiatry 2010; 196: 139-42.

21 Fok M, Hotopf M, Stewart R, Hatch S, Hayes R, Moran P. Personality disorder and self-rated health: a population-based cross-sectional survey. J Pers Disord 2013; 119: 1-15.

22 Crawford MJ, Price K, Gordon F, Josson M, Taylor B, Bateman A, et al. Engagement and retention in specialist services for people with personality disorder. Acta Psychiatr Scand 2009; 119: 304-11.

23 Office for National Statistics. Ethnic Group Statistics. A Guide for the Collection and Classification of Ethnicity Data. HMSO, 2003.

24 Office for National Statistics. Census: People and Society; Ethnic group (data tables). London, United Kingdom: Office for National Statistics. ONS, 2001 (http://www.neighbourhood.statistics.gov.uk/dissemination/ datasetList.do\#10).

25 Office for National Statistics. Beginner's Guide to UK Geography - Super Output Areas (SOAS). ONS, 2007 (http://www.statistics.gov.uk/geography/ beginners_guide.asp).

26 Shaw RJ, Atkin K, Bécares L, Albor CB, Stafford M, Kiernan KE, et al. Impact of ethnic density on adult mental disorders: narrative review. Br J Psychiatry 2012; 201: 11-9.

27 Noble M, Wright G, Smith G, Dibben C. Measuring multiple deprivation at the small-area level. Environ Plan A 2006; 38: 169-85.

28 Fagg J, Curtis S, Stansfeld S, Congdon P. Psychological distress among adolescents, and its relationship to individual, family and area characteristics in East London. Soc Sci Med 2006; 63: 636-48.

29 Das-Munshi J, Becares L, Dewey ME, Stansfeld SA, Prince MJ. Understanding the effect of ethnic density on mental health: multi-level investigation of survey data from England. BMJ 2010; 341: c5367.
30 Stafford M, Becares L, Nazroo J. Objective and perceived ethnic density and health: findings from a United Kingdom general population survey. Am J Epidemiol 2009; 170: 484-93.

31 Karlsen S, Nazroo JY, Stephenson R. Ethnicity, environment and health: putting ethnic inequalities in health in their place. Soc Sci Med 2002; 55 1647-61.

32 Ecob R, Williams R. Sampling Asian minorities to assess health and welfare. $J$ Epidemiol Community Health 1991; 45: 93-101.

33 Shields MA, Wailoo A. Exploring the determinants of unhappiness for ethnic minority men in Britain. Scott J Polit Econ 2002; 49: 445-66.

34 Beck CT. Predictors of postpartum depression: an update. Nurs Res 2001; 50 : 275-85.

35 Robertson E, Grace S, Wallington T, Stewart DE. Antenatal risk factors for postpartum depression: a synthesis of recent literature. Gen Hosp Psychiatry 2004; 26: 289-95.

36 Lancaster CA, Gold KJ, Flynn HA, Yoo H, Marcus SM, Davis MM. Risk factors for depressive symptoms during pregnancy: a systematic review. Am J Obstet Gynecol 2010; 202: 5-14.

37 Propper C, Jones K, Bolster A, Burgess S, Johnston R, Sarker R. Local neighbourhood and mental health: evidence from the UK. Soc Sci Med 2005; 61: 2065-83.

38 Boydell J, van Os J, McKenzie K, Allardyce J, Goel R, McCreadie RG, et al. Incidence of schizophrenia in ethnic minorities in London: ecological study into interactions with environment. BMJ 2001; 323: 1336-8.

39 Kirkbride JB, Morgan C, Fearon P, Dazzan P, Murray RM, Jones PB. Neighbourhood-level effects on psychoses: re-examining the role of context. Psychol Med 2007; 37: 1413-25.

40 Kirkbride JB, Boydell J, Ploubidis GB, Morgan C, Dazzan P, McKenzie K, et al. Testing the association between the incidence of schizophrenia and social capital in an urban area. Psychol Med 2008; 38: 1083-94.

41 O'Hara MW, Swain AM. Rates and risk of postpartum depression - a metaanalysis. Int Rev Psychiatry 1996; 8: 37-54.

\title{
extra a humbling experience
}

\section{Owen Haeney}

I recently visited Uganda as a visiting clinician. After seeing the first patient, a child, my host asked about UK treatments. I admitted my uncertainty, since I had not treated a child for over a decade. I had a similar response when asked about an elderly man with dementia. The next patient presented in catatonia which prompted mutterings from me about the rarity of the condition at home. And another had psychiatric sequelae of a tropical disease, which left me amazed by the breadth of pathology. I confessed my awe at what Ugandan doctors had to know. 'Oh, I'm not a doctor, I'm a clinical assistant' he replied. 'I couldn't do what you do!' 